\title{
Water Resource Conservation Planning for Micro-Watershed of Devanayakanahalli in Tumkur District using Geospatial Technology
}

\author{
Anand Gouda*, K. S. Rajashekarappa, T. Chikkaramappa, K. Devaraja and S. Shivaraj \\ University of Agricultural Sciences, CAE, GKVK, Bengaluru, India \\ *Corresponding author
}

\section{A B S T R A C T}

K e y w o r d s
GIS, Micro-
watershed, Land
use, Land cover
map, Water
resource
management
Article Info
Accepted:
28 November 2020
Available Online:
10 December 2020

\section{Keywords}

GIS, Microuse, Land cover map, Water resource management

Article Info

Accepted: Available Online: 10 December 2020
Geospatial technique were used for land and water management action plan for Devanayakanahalli micro-watershed lies between $76^{\circ} 39^{\prime} 43^{\prime \prime}$ to $76^{\circ} 41^{\prime} 17^{\prime \prime}$ E longitudes and $13^{\circ} 4^{\prime} 54^{\prime \prime}$ to $13^{\circ} 6^{\prime} 2^{\prime \prime} \mathrm{N}$ latitudes in Tumkur district, Karnataka. Arc GIS software was used in evaluation of morphological characteristics of the micro-watershed. The present study reveals that drainage pattern was dendritic with trunk order 3 . The area, perimeter, maximum length and width of the micro-watershed are $453 \mathrm{ha}, 10.10 \mathrm{~km}, 3.68$ $\mathrm{km}$ and $1.23 \mathrm{~km}$ respectively. The mean value of bifurcation ratio was 2.20 , it indicates micro-watershed had suffered less structural disturbance. The value of drainage density $2.30 \mathrm{~km} \mathrm{~km}^{-2}$ which shows that the region having permeable subsoil material. The value of form factor illustrates micro-watershed was elongated in shape. The study were used to prepare the thematic maps of land use/land cover, soil, slope and drainage using satellite imagery data and Survey of India (SoI) toposheet of micro-watershed and to integrate all the maps under GIS environment to prepare the water resource management plans for micro-watershed. The study will be helpful in identification of sites for construction of different soil and water conservation structures. Thus, the results shows that 38.14 per cent of the total area is ideal for constructing check dam, 20.97 per cent farm pond and 13.40 per cent for percolation pond which helps in sustainable development of the natural resources of the micro-watershed with the proper implementation of the proposed action plans.

\section{Introduction}

Water is one of the essential natural resource for the survival of life on Earth. Water is a boon of nature for the whole living world and is essential for variety of purposes to human being as well as to plants and animals. Demand for water is increasing day by day, with the ever increasing population, resulted severe water crisis. Land and water are the life sustaining resources of the world, which are undergoing a rattling stress because of increasing anthropogenic pressure on these finite resources for the primary needs and thereby affecting the future food security. Water is probably the only natural resource to touch all aspects of human civilization from agricultural and industrial development. Hence, we need proper management and development plan to conserve, restore or 
recharge water, where soil loss is very high due to various topographical conditions.

The total water resources in seven river basins are 7663 TMC. Approximately 58 per cent of water resources are found in west flowing rivers, a larger percentage of water could not be harnessed for effective use. The average annual yield of the rivers of Karnataka has been roughly estimated as 3475 TMC (Anon.,2015). Karnataka has given an important place for watershed development because 75 per cent of the cropped area in Karnataka depends on rainfall. The geographical area of the State is 190.50 lakh ha, under that only 129.70 lakh ha is available for watershed development.

The micro-watershed is located in Central Karnataka Plateau, with a hot climate, comes under semi-arid eco-sub region, with a hill region. The soils in this region are erosion prone and less productive above condition of the region there is requirement of soil and water conservation measures and proper watershed planning. Therefore, for planning of selected micro-watershed, the morphological characteristics, land use/ land cover classification, drainage pattern, hydro geomorphology, soil, land slope, etc., and runoff estimation were studied and analysed.

\section{Materials and Methods}

\section{Study area}

The present study is a part of the Southern dry zone of Karnataka under semiarid region and subtropical climate and it was taken up in Devanayakanahalli micro-watershed located in Turvekeretaluk of Tumkur district, Karnataka state (Fig. 1) and having total area of 453 ha which lies between $76^{\circ} 39^{\prime} 43^{\prime \prime}$ to $76^{\circ} 41^{\prime} 17^{\prime \prime}$ E longitudes and $13^{\circ} 4^{\prime} 54^{\prime \prime}$ to $13^{\circ}$ 6 ' 29" N latitudes with an average altitude of 450-800 $\mathrm{m}$ above MSLand located in the
Southern part of Tumkur district. The study area is located at Turvekere taluk about 120 $\mathrm{km}$ from Bengaluru city and it is falling under the Survey of India toposheet of D43Q12 $(1: 50,000)$. December is the coldest month with mean daily minimum temperature of $9.8^{\circ} \mathrm{C}$, while May is the hottest month with mean daily maximum temperature of $36.10^{\circ} \mathrm{C}$. Relative humidity of over 77.19 per cent is common during monsoon period. The average annual rainfall of the study area is $768.6 \mathrm{~mm}$ during the year of 2011-2017. Nearly, 55.02 per cent of the rain received during the southwest monsoon period (June-September) and the northeast contributes about 23.4 per cent.

In the present research work the manual method of watershed delineation has been followed. In manual method, the drainage lines and contours are taken as the reference. First a point is chosen as the watershed outlet, which will be the pore point for all the water draining out of that watershed. Watershed boundary is delineated by drawing lines perpendicular to the elevation contours for the land that drains to the point of interest. According to All India Soil and Land Use Survey the study area falls under the watershed codification of 4B3D1P1c.The flow chart of methodology is presented in Fig. 2.

The assessment of hydrological characteristics of a drainage basin is a mandate for any basin management scheme. The geo-morphological characteristics of the micro-watershed were determined by digitizing the drainage networks in SoI toposheet using Arc GIS software and subsequent cleaning, editing and assigning topology produced a database in terms of linear, aerial and relief aspects of the watershed. It involves a detailed morphometric analysis, which includes basin size, shape, slope of drainage area, drainage 
density, size and length of the tributaries. Morphometric analysis of a watershed provides a quantitative description of the drainage system, which is an important aspect of the characterization of watersheds (Strahler, 1964).

Using ArcGIS 10.2 version, various thematic maps were generated such as drainage map, contour map, slope map, soil map, lineament map, ground water prospect map and land use/land cover map as a spatial database with the help of DEM, Satellite image and Ground truth data in GIS environment. Digital Elevation Model (DEM) and Satellite image (Fig. $3 \& 4$ ) is an important parameters in resource management applications which was downloaded from the Bhuvan official website by selecting "Bhuvan data archive" option and giving extreme boundaries longitude and latitude values in the website (http://bhuvan.nrsc.gov.in).

As per Integrated Missions for Sustainable Development (IMSD) guidelines, percolation pond is normally suggested for recharging aquifer and used where surface storage is available for a restricted period. The required site conditions are high permeability and higher stream order. Check dams are used for surface storage and site conditions are well defined straight stream channel with level banks. Farm ponds are normally used for livestock storage and restricted irrigation. Narrow elongated depression, gentle slope and small catchment area are the required site condition for the farm ponds. The IMSD site selection criteria for water harvesting structures are given in Table 1 (Naseef and Thomas, 2016).

\section{Results and Discussion}

The results of the study conducted in Devanayakanahalli micro-watershed on geomorphological features like linear, aerial and relief aspects, preparation of thematic maps in the GIS platform which were further used for planning of suitable soil and water conservation structures. In the present study Survey of India toposheet of 1:50,000 scale was used for delineating the boundary of Devanayakanahalli micro-watershed. The boundary was delineated using the ArcGIS 10.2.2 version. The total area of microwatershed and its perimeter were found to be 453 ha and $10.10 \mathrm{~km}$ respectively.

\section{Morphometric analysis}

From the results it is revealed that drainage pattern of the study area is dendritic with trunk order 3 which is represented in Fig.5. The maximum length and width of the watershed were $3.68 \mathrm{~km}$ and $1.23 \mathrm{~km}$ respectively. The mean value of bifurcation ratio is 2.20 indicated, that micro-watershed has suffered less structural disturbance and drainage pattern has not been distorted(Nag, 1998). The value of drainage density is 2.30 $\mathrm{km} \mathrm{km}{ }^{-2}$ which indicated that, the region is having permeable subsoil material and good vegetation cover (Mallik et al., 2011). The value of form factor indicates microwatershed is approaching towards elongated shape of watershed. Time of concentration directly influences on runoff generation from the watershed. For the present study the time of concentration is $54 \mathrm{~min}$ and it indicates more time is required for water to travel from the most distant part of watershed to its outlet.

\section{Thematic maps}

\section{Slope map}

The slope map was derived using the DEM for the study area from slope map, it was observed that, the major part of the microwatershed had gentle slope (209.60ha) followed by the moderately sloping (191.90 ha) land. Both gentle and moderately sloping 
areas were majorly distributed over the entire micro-watershed. Only fewer parts of microwatershed had nearly level slope (23.70 ha). Strongly sloping lands were observed in south-western parts and immediately above the centre of micro-watershed of slope map (Fig. 6). Compared to the gentle and moderate slopes, strongly sloping lands were in a limited areal extent (22.46 ha). Very fewer parts of the micro-watershed had steep sloping land and its areal extent was less than 5.34 ha of the micro-watershed area.

\section{Soil texture map}

The recharge capacity and groundwater quality is decided by the soil types and their texture. In the study area, three textural classes were found and areal extent of each texture class were found to be loamy sand (194 ha), sandy clay loam (123 ha), and sandy loam (114 ha) and soil texture with their areal extent is shown in Fig. 7.The infiltration rate depends on the soil texture as in sandy soil the infiltration rate is higher than silty soil. In a clayey soil it may be initially high (for heavy black clay with cracking), but becomes low when the soil is moist to wet. From analysis it was found that, sandy loam and sandy clay loam distributed entirely throughout the micro-watershed.

\section{Land use/ land cover map}

Land use/land cover map (Fig. 8) was prepared from the LISS-III satellite data dated March 2016 downloaded from the official Bhuvan website. The FCC necessary for the land use/land cover classification for the present study was prepared by using the same band combination. Supervised classification was done using some training sets. The results obtained under this were very close to the ground truth data. After the supervised classification of LISS-III satellite image under
Arc GIS software, the areal extent of land use types viz., agricultural land, plantation, waste land, built up land and Water bodies were found to be $371,41,28,5$ and 8 ha, respectively. The obtained results indicate that, micro-watershed was having more Crop land area followed by agricultural plantation, waste land/fallow land and there was only a small portion of built up land. For classifying using supervised method, the selected areas were identified by some ground truth values. Agriculture land forms a major land use and major crops observed in the study region ragi, groundnut, red gram and horticulture crops like coconut and arecanut are the different crops grown in that area. Agronomic measures viz., multching, ploughing across the slope, use of resistant varieties is suggested for moisture conservation.

\section{Identification of suitable sites for water harvesting structures}

Identification of suitable sites for water harvesting structures is made by overlaying land use, soil, slope, runoff potential, soil permeability and stream order map. The criteria assigned are based on the IMSD guidelines. The proposed sites for check dams, farm ponds and percolation ponds, are shown in Fig. 9. The study area reveals that check dams are proposed on $1^{\text {st }}$ to $3^{\text {rd }}$ order streams of micro-watersheds which can irrigate 20 ha of land and covers 38.14 per cent of the total area is ideal for constructing check dam in study site. Farm pond can be suggested which is generally dugout ponds created by excavating pits in an area having flat topography and location having low soil permeability which can occupies 20.97 per cent of the total area is feasible for farm pond and 13.40 per cent area for percolation pond. Proposed check dam could be useful for protective irrigation and percolation pond augment ground water table. 
Table.1 Site selection criteria for water harvesting structures

\begin{tabular}{|c|c|c|c|c|c|}
\hline Structure & $\begin{array}{c}\text { Slope } \\
(\%)\end{array}$ & Permeability & Runoff & $\begin{array}{c}\text { Stream } \\
\text { Order }\end{array}$ & $\begin{array}{c}\text { Catchment } \\
\text { Area (ha) }\end{array}$ \\
\hline Farm Pond & $0-5$ & Low & Medium/High & 1 & $1-2$ \\
\hline Check Dam & $<15$ & Low & Medium/High & $1-4$ & $>25$ \\
\hline Percolation Pond & $<10$ & High & Low & $1-4$ & $25-40$ \\
\hline
\end{tabular}

(Shivaraj et al., 2019)

Fig.1 Location map of study area

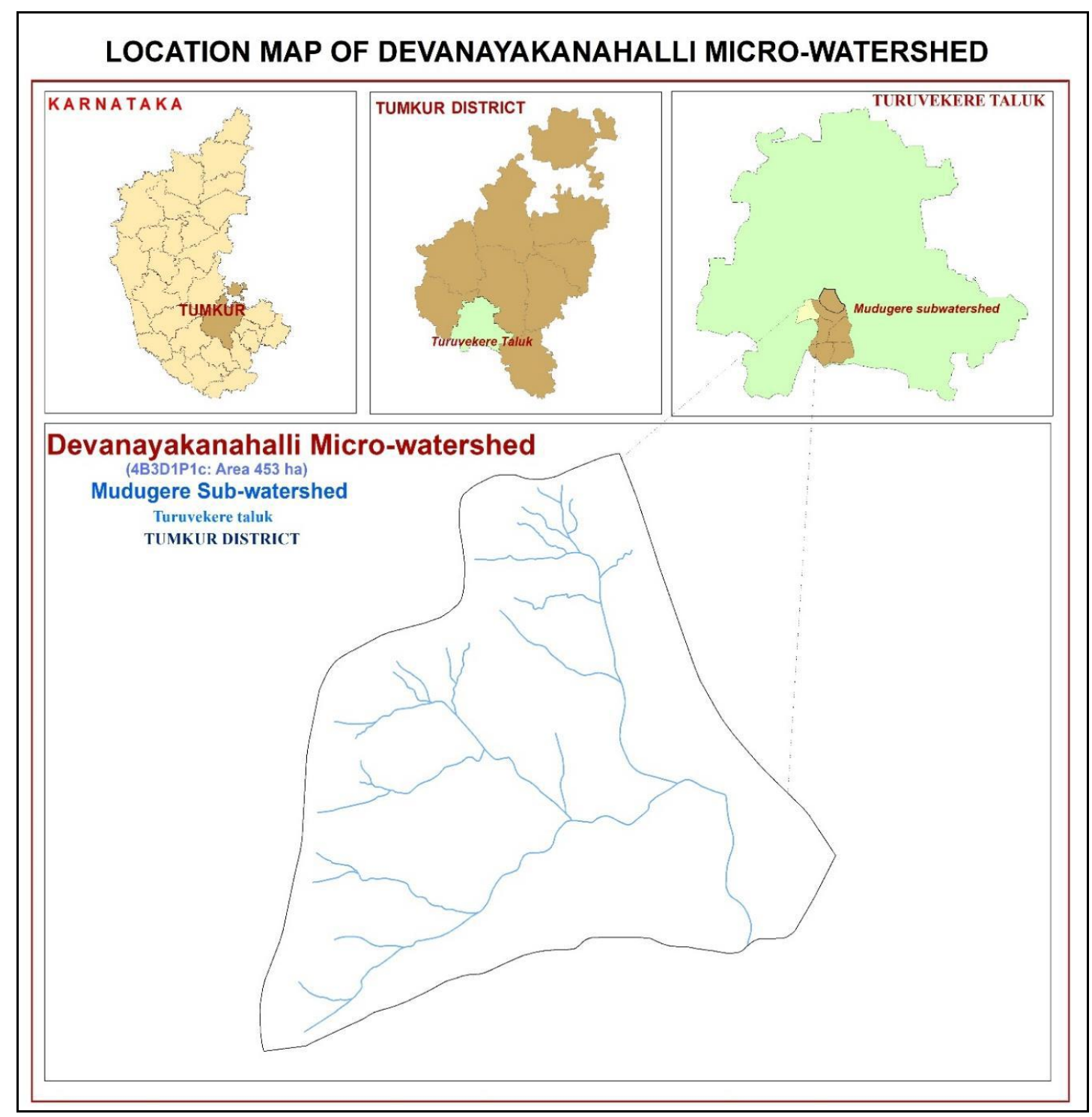


Fig.2 Drainage map of Devanayakanahalli micro-watershed

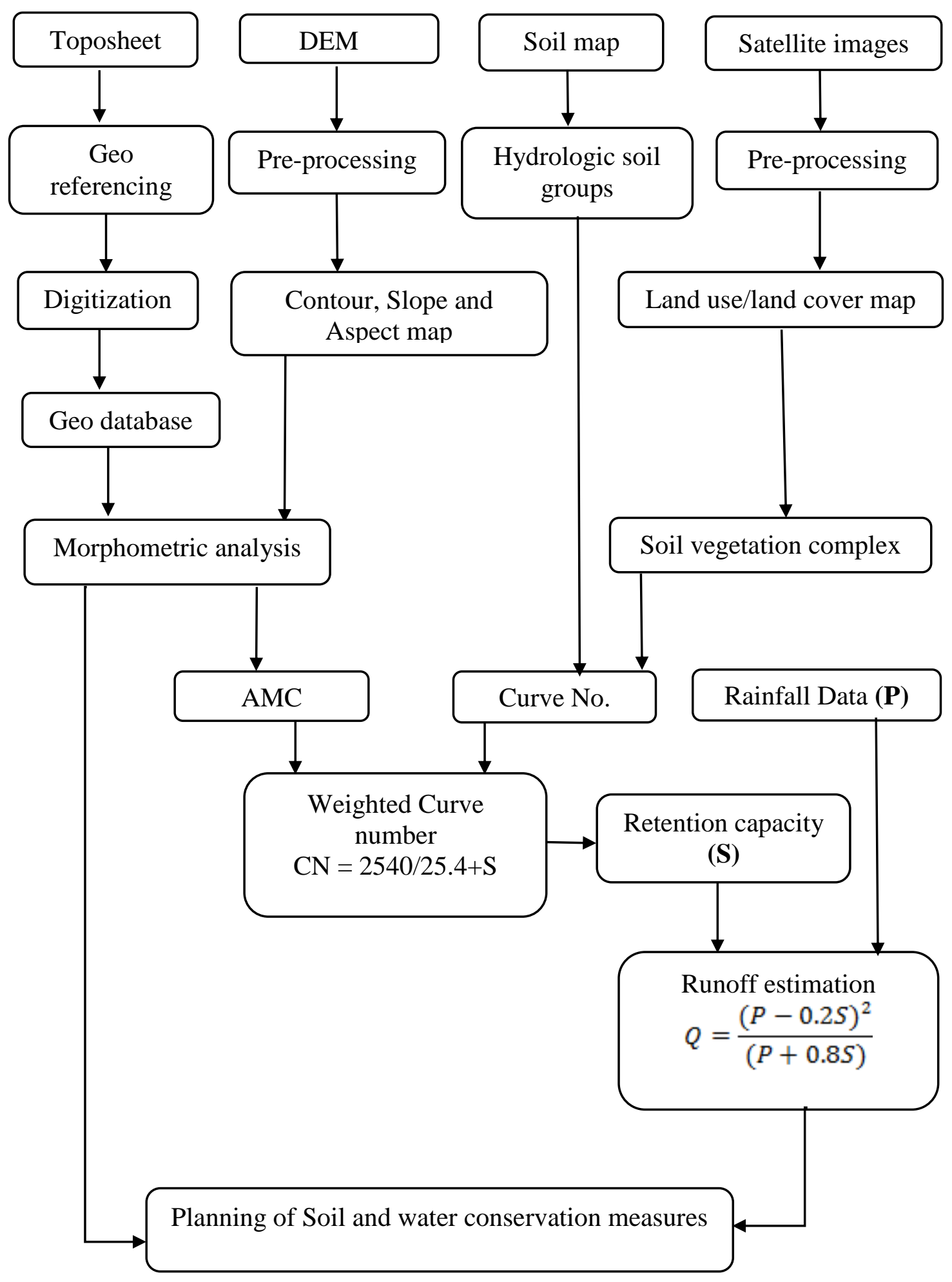


Fig.3 DEM map of Devanayakanahalli micro-watershed

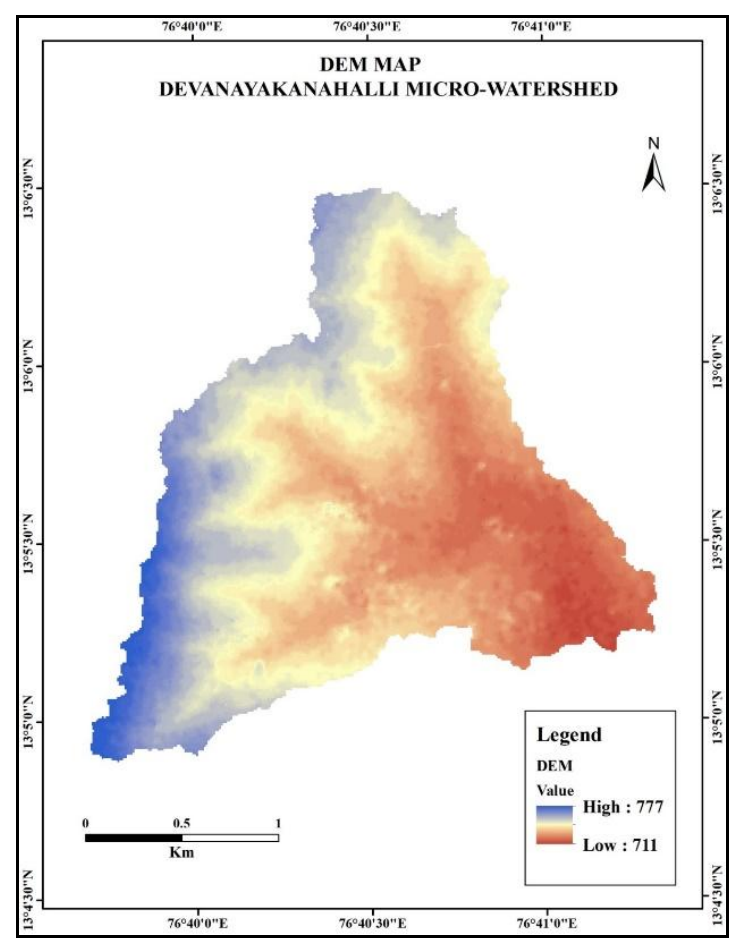

Fig.5 Drainage map of Devanayakanahalli micro-watershed

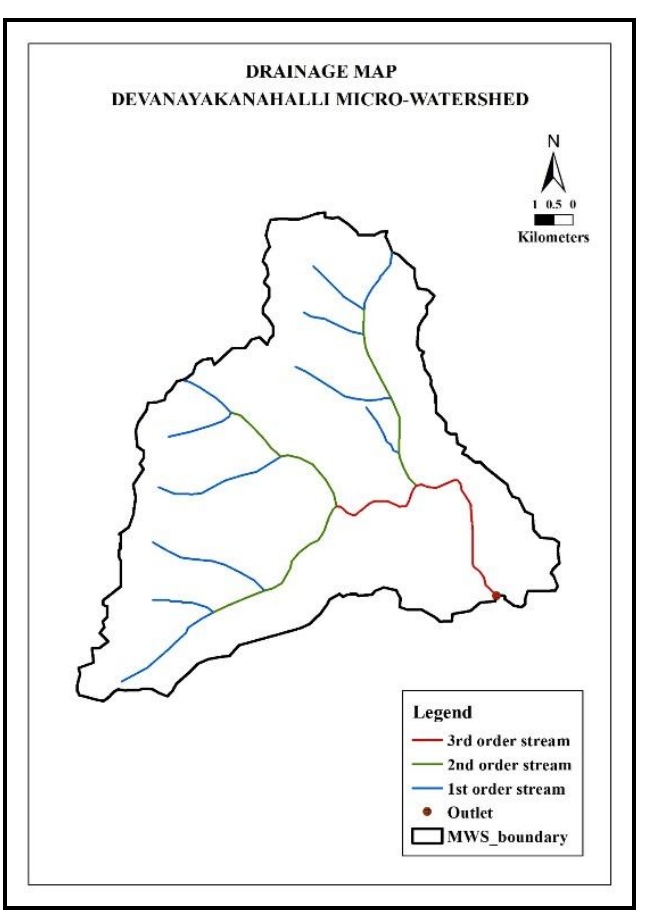

Fig.4 Satellite image of Devanayakanahalli micro-watershed

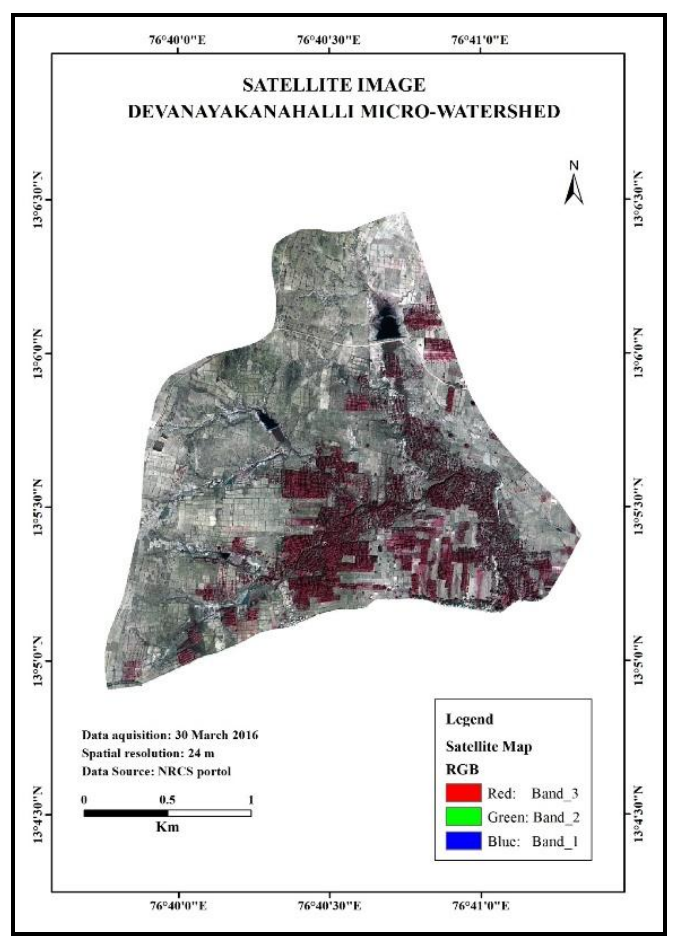

Fig.6 Slope map of Devanayakanahalli micro-watershed

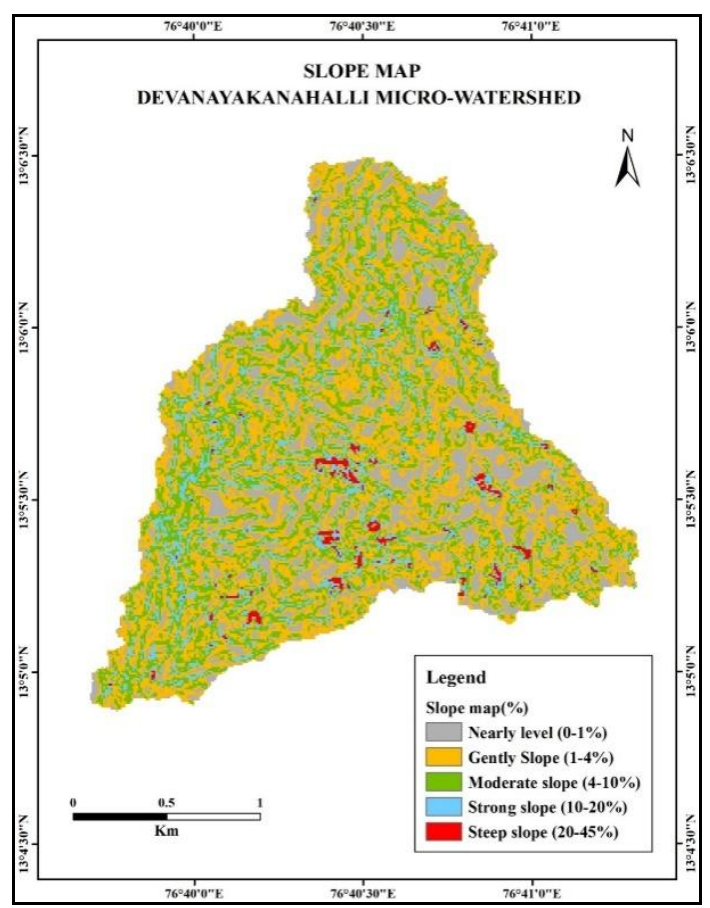


Fig.7 Soil map of Devanayakanahalli micro-watershed

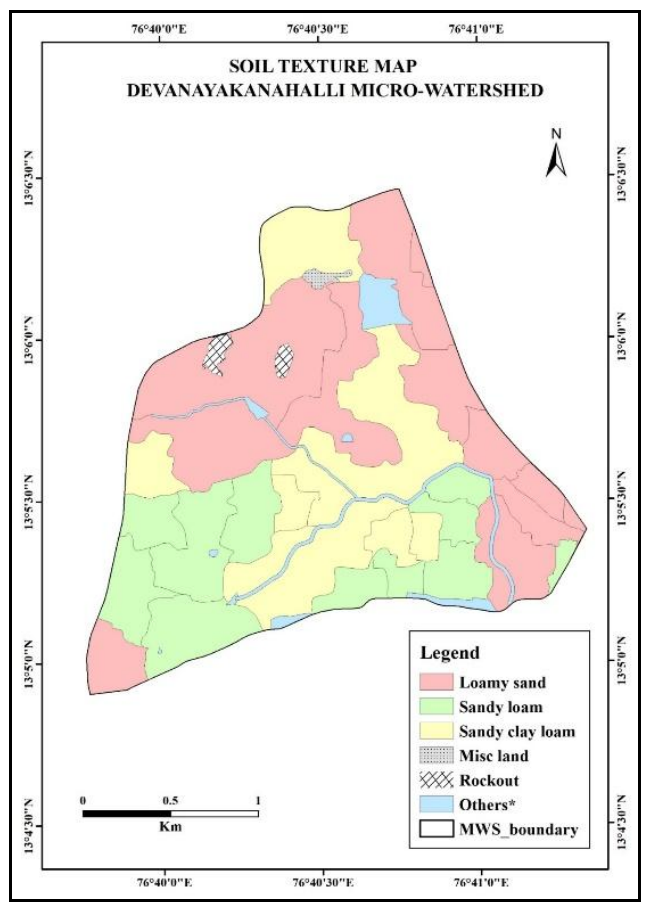

Fig.8 LULC map of Devanayakanahalli micro-watershed

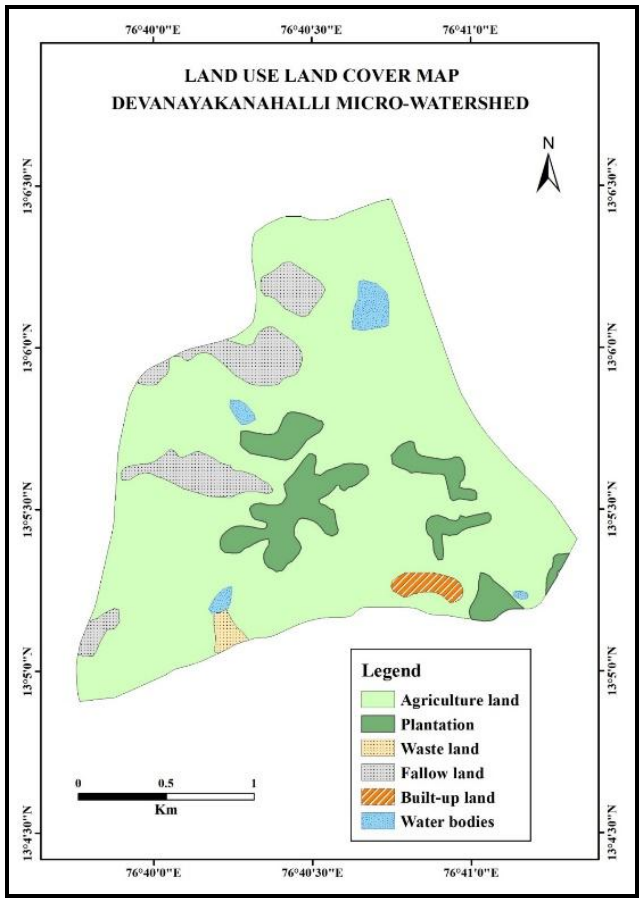

Fig.9 Proposed sites of water harvesting structures for Devanayakanahallimicro-watershed

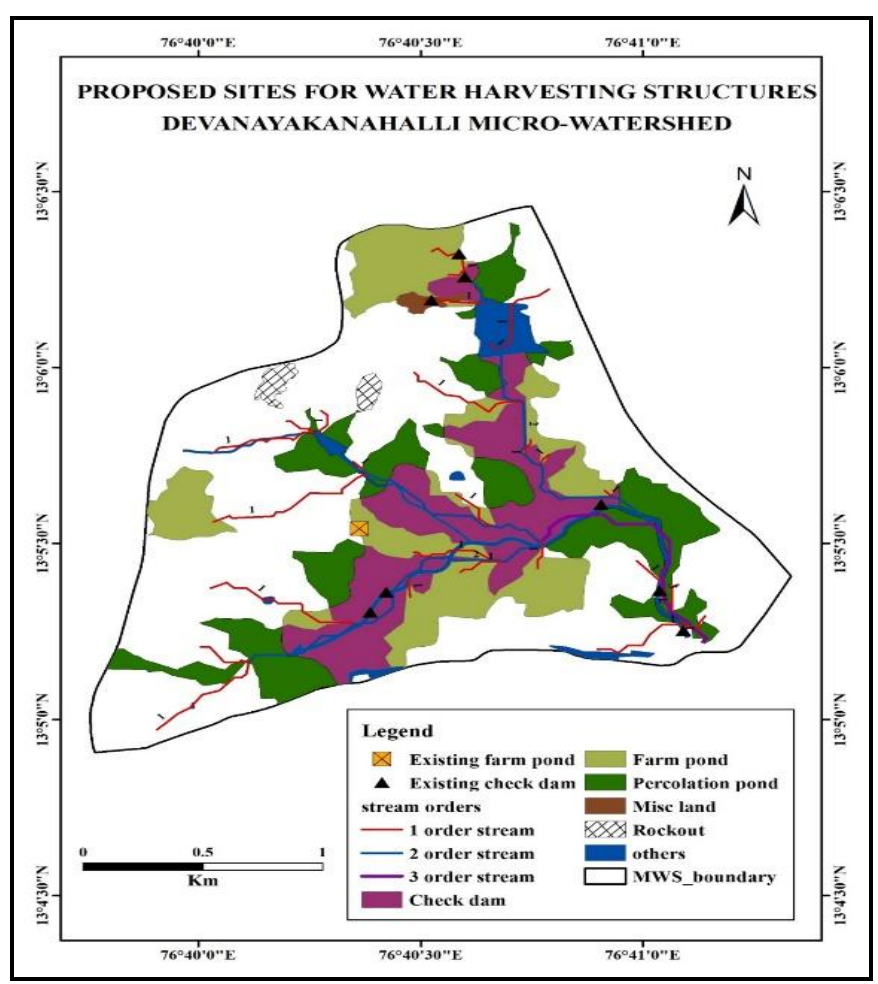


Locations of water harvesting structures are suggested by conducting meteorological and topographical analysis. However, for the practical implementation of these structures, viability of other considerations such as economy, social implications, practical feasibility etc., need to be considered. By adopting proper planning for water conservation measures additional surface water resources can be developed by constructing different water harvesting structures under different land use/cover units and also by increasing the storage capacity of the existing major tanks within the microwatershed area.

Conclusion of the study:

Devanayakanahalli micro-watershed had $3^{\text {rd }}$ order trunk stream and drainage pattern was dendritic which indicates the homogeneity in texture and lack of structural control.

The values of drainage density, drainage texture and texture ratio were found to be $2.30 \mathrm{~km} \mathrm{~km}^{-2}, 1.48 \mathrm{~km}^{-1}$ and 1.08 $\mathrm{km}^{-1}$,respectively and these values indicates that, micro-watershed has permeable sub soil geology and good vegetation cover.

From the relief aspect it was found that, time of concentration is $54 \mathrm{~min}$. It indicates more time is required for water to travel from the most distant part of micro-watershed to outlet and leads to low runoff due to permeable soils in study area.

From analysis it was found that, sandy loam and sandy clay loam distributed entirely throughout the microwatershed which generates low runoff in the study area due to more infiltration of the soil

The result shows that 38.14 per cent (125.27 ha) of the total area is ideal for constructing check dam, 20.97 per cent
(68.88 ha) for farm pond and 13.40 per cent (44.01 ha) for percolation pond. Whereas, practical implementation of these structures, viability of other considerations such as economy, social implications, practical feasibility etc., need to be considered.

Annual rainfall for the year 2015 was recorded as $1028 \mathrm{~mm}$ and runoff depth was found to be $220 \mathrm{~mm}$. About 808 $\mathrm{mm}(78.59 \%)$ of rainfall could be absorbed through infiltration within bunding system. Out of $220 \mathrm{~mm}$ runoff, $48.6 \mathrm{~mm}(5.8 \%)$ runoff was available in existing storage structures and remaining $34 \mathrm{~mm}(3.30 \%)$ was allowed as environmental flow, rest $137.4 \mathrm{~mm}(13.40 \%)$ of runoff will be available for harvesting.

The use of GIS can make the cumbersome geomorphological analysis as an easy task as compared to traditional methods. It saves time and helpful in planning of resource conservation techniques in the watershed area for sustainable development.

\section{References}

Anonymous, 2005, Watershed atlas of Karnataka (sub, mini and micro watersheds). Karnataka state remote sensing applications centre, Dept. of IT, BT, S \& T. Govt. of Karnataka, Bangalore. p. 12.

Anonymous, 2015, A plan for action, report of the national commission for integrated water resources development and central water commission, Ministry Water Res., New Delhi. pp. 12-34.

Mallik, M. I., Bhat, M. S. and Kuchay, N. A., 2011, Watershed based drainage morphometric analysis of Lidder catchment in Kashmir valley using GIS. Recent Res. Sci. Tech., 3(4): 118-126.

Nag, S. K., 1998, Morphometric analysis 
using remote sensing techniques in the Chaka sub-basin, Purulia district, West Bengal. J. Indian Soc. Remote Sensing, 26(1): 69-76.

Naseef, A. U. T. and Thomas, R., 2016, Identification of suitable sites for water harvesting structures in Kecheri river basin. Int. Conf. Emerging Trends Engg. Sci. Tech., 24: 7-14

Shivaraj, Rajashekarappa, K. S. and Chikkaramappa T., 2019, Site Selection for Water Harvesting Structures in Halayapura-1 micro-watershed of Tumkur District Using GIS \& RS Applications. Int. Con. Soil Conservation Soc. India.

Strahler, A. N., 1964, Quantitative geomorphology of drainage basin and channel networks. Handbook of applied hydrology, 23: 543-552.

http://bhuvan.nrsc.gov.in

\section{How to cite this article:}

Anand Gouda, K. S. Rajashekarappa, T. Chikkaramappa, K. Devaraja and Shivaraj, S. 2020. Water Resource Conservation Planning for Micro-Watershed of Devanayakanahalli in Tumkur District using Geospatial Technology. Int.J.Curr.Microbiol.App.Sci. 9(12): 3339-3348. doi: https://doi.org/10.20546/ijcmas.2020.912.398 